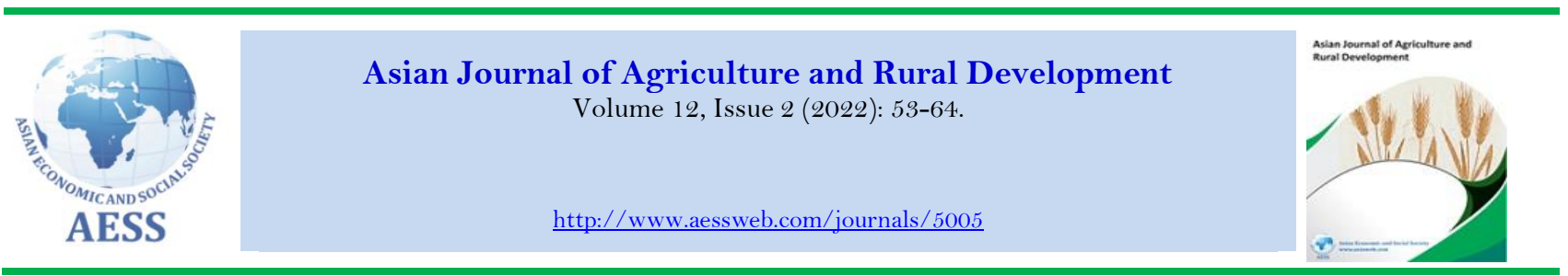

\title{
UNDERSTANDING MARKET BEHAVIOR ON CORN COMMODITY: PHENOMENON AT YEAR END
}

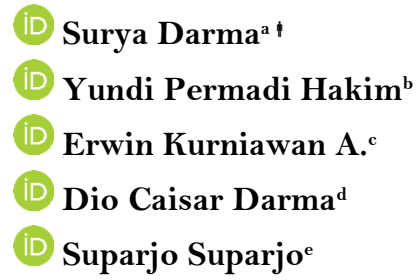

\section{Article History}

Received: 30 December 2021

Revised: 3 February 2022

Accepted: 18 February 2022

Published: 8 March 2022

\section{Keywords \\ Demand \\ Supply \\ Corn \\ Interviews \\ Samarinda \\ End of year.}

\author{
${ }^{a}$ Department of Agroecotechnology, Faculty of Agriculture, Universitas Mulawarman, \\ Indonesia. \\ ${ }^{b, d}$ Department of Management, Sekolah Tinggi Ilmu Ekonomi Samarinda, Indonesia. \\ 'Department of Economics, Faculty of Economics and Business, Universitas Mulawarman, \\ Indonesia. \\ 'Department of Geomatics Technology, Polytechnic Pertanian Negeri Samarinda, \\ Indonesia.
}

\section{- $\$$ surya_darma@faperta.unmul.ac.id (Corresponding author)}

Contribution/Originality: The orientation of this study emphasizes and focuses on the increase in the demand and supply sides of corn commodity. Although livestock commodities (e.g., chicken) and plantation commodities (e.g., coffee and tobacco) have also increased by the end of the year, the most popular commodity in Indonesia is food crops such as corn. Another feature that this study offers is its focus on Samarinda City, where the market depends not only on consumer demand but also on attractive offers from producers.

DOI: $10.55493 / 5005 . v 12 \mathrm{i} 2.4434$

$\operatorname{ISSN}(\mathrm{P}):$ 2304-1455/ ISSN(E): 2224-4433

How to cite: Surya Darma --- Yundi Permadi Hakim --- Erwin Kurniawan A. --- Dio Caisar Darma --- Suparjo Suparjo (2022). Understanding Market Behavior on Corn Commodity: Phenomenon at Year End. Asian Journal of Agriculture and Rural Development, 12(2), 53-64. 10.55493/5005.v12i2.4434

(C) 2022 Asian Economic and Social Society. All rights reserved.

\section{INTRODUCTION}

This study looks at market anomalies in the demand for corn commodities during the year-end celebrations in Samarinda City. Generally, the end of the year is when people spend a lot of time with family and friends. New Year 
celebrations are often in the spotlight for economists and policy makers (such as Resnik \& Elliott (2016); Aya (1979)). Severe increases in commodities, services and goods must be must be suppressed so that prices do not soar causing 'hyperinflation' (Farandy, 2020). Sometimes farmers also benefit from inflation from the demand aspect (Paul, Jahan, Nandi, \& Rahman, 2021). It's just a matter of how producers present their goods or services at relevant prices in the market (Darma, Wijaya, \& Darma, 2020).

Besides Christmas, New Year has been enthusiastically celebrated since the $18^{\text {th }}$ century until now (Schmidt, 1991). It is not surprising that the demand for products, services and goods has exploded (Yijo et al., 2021). Even though this benefits the welfare of farmers, it can cause harm for consumers (Darma, Maria, Lestari, \& Darma, 2020). Indonesia has different cultural characteristics from other countries in the celebration of the new year (Rianti, Novenia, Christopher, Lestari, and Parassih (2018)). The most striking difference is the consumption of food and drinks, which are less favored by most people, where Indonesian people often process corn to be used as a main dish (Wijaya, 2019). They serve these preparations grilled, fried, or boiled, and the use of corn at the turn of the year has become a special tradition.

According to Rosas-Castor, Guzmán-Mar, Hernández-Ramírez, Garza-González, \& Hinojosa-Reyes (2014), corn, which in Latin is 'Zea mays L' (or maize) is a food crop. Corn contains a lot of carbohydrates, so it is one of the staple food sources in Indonesia after rice (Nuss \& Tanumihardjo, 2010). Because corn is a favorite commodity in Indonesia, it exists in various community groups (Arifin, 2013). Another important aspect is that corn is easy to grow (Sandhu et al., 2020). In a global context, the average temperature to produce maize ranges from $18^{\circ} \mathrm{C}-33^{\circ} \mathrm{C}$ with a minimum rainfall of $800 \mathrm{~mm}$ per year and a maximum of 2,300 $\mathrm{mm}$ per year (Ferrero, Mauricio, \& Gonzalez-Andujar, 2014; Wang et al., 2020). With relatively cheap capital, corn production is not a big constraint. As is known, Samarinda City is the center of the East Kalimantan Province in Indonesia, which has a high level of consumptive tendencies (Wijaya, Darma, \& Darma, 2020). The high level of per capita income is the main reason for the population's prosperity. They channel most of their spending on non-food needs, such as ceremonies and parties, insurance and tax collections, health and education costs (BPS of Samarinda City, 2021 b; Wijaya, Zainurossalamia, \& Darma, 2020). However, the factor of special celebrations, such as the end of the year, increases the need for food and horticultural crops. Customs, traditions, and culture cannot be separated because all three have become part of history (Indriastuti, Kasuma, Zainurrosalamia, Darma, \& Sawangchai, 2020). The complexity of the paper is demonstrated based on five plots, including the introduction, theoretical lens, methods, results and discussion, and conclusions.

\section{THEORETICAL LENS}

Moss (1974) illustrates that supply and demand are the most vital parts of market economics. 'Law of demand' and 'law of supply' are basic theories that explain the interaction between sellers and buyers for a resource (Inoua \& Smith, 2020). The two laws represent the relationship between the price of a service or product, the number of people who buy it, and its availability (Parro, 2019). Both demand and supply are inversely related, which affects the price of the goods or services sold. These conditions are interpreted as a 'demand curve' and a 'supply curve' (Safiullin, Oduntsova, \& Safiullin, 2015).

Demand is a term for the amount of goods and services that are desired at a certain time and price level according to the market (Mazurek, García, \& Rico, 2019). The 'law of demand' applies when the price of a product or service falls and the quantity demanded increases. On the other hand, when the price of goods demanded increases, demand will decrease (Wirtz, So, Mody, Liu, \& Chun, 2019). The crucial factor influencing demand is consumer tastes (Harahap, Amanah, Harahap, \& Jubaidah, 2019). Increased consumer tastes trigger an increase in demand (Purcell \& Lusk, 2003), for example, with certain fruits whose stock is scarce and will therefore be more expensive (Hovhannisyan, Kondaridze, Bastian, \& Shanoyan, 2020). Another factor is the price of substitute goods (Milgrom \& Strulovici, 2006). For example, when the price of coffee is high, people will start shopping for tea because it costs less. Several factors that influence demand include the proportion of needs, prices, income levels, and population (Sorrell, 2015). Figure 1 illustrates a simple demand curve that demonstrates the general relationship between the number of consumer purchases of goods and services in a given period.

In contrast to demand, the 'law of supply' occurs when the price of goods rises, encouraging an increase in supply. If the price increases, production will also increase, but when the price decreases, producers are reluctant to reduce supply (Ai-Hua, 2012). The crucial factor that determines supply is the cost of production. The lower the cost of production, the cheaper the goods that can be produced and therefore supply can increase (as per the example given by Aday \& Aday (2020)). Future speculation is the second factor, where predictions of future price increases allowing people to withhold goods or services. The last element is technology. Advances in technology will result in more efficient production processes.

Figure 2 shows the 'supply curve'. If the slope is curving upward, it causes the price of goods and services to increase or become more difficult to obtain because each additional unit is scarce. Then, the cost of production becomes much more expensive and the price is much higher than usual. Unexpectedly, when prices soar, there is more incentive to increase production (MacDonald, 2000). The 'classical economic theory' represents a short-run approach (Davidson, 1999).

Interestingly, supply and demand are opposites. Both will reach a point of market equilibrium when they meet each other, which is referred to as the 'law of demand' and the 'law of supply' (Jehle \& Reny, 2011). In fact, these two laws explain the harmony between the quantity and the price offered. They then connected this to a 'demand curve' and a 'supply curve'. At a certain point in time, the supply of goods brought to the market is fixed. In other words, the 'supply curve' is a vertical line, while the 'demand curve' is always downward sloping because of the diminishing law of marginal utility. When it reaches this point of equilibrium, the price of a commodity and its demand will be stable, 
or not change at all (Humphrey, 1992). Sellers also can no longer raise the prices borne by consumers (Alam \& Uddin, 2009). However, in the long term, they can increase or decrease the stock to change the market price to the expected level (Haugen, Talmor, \& Torous, 1991).

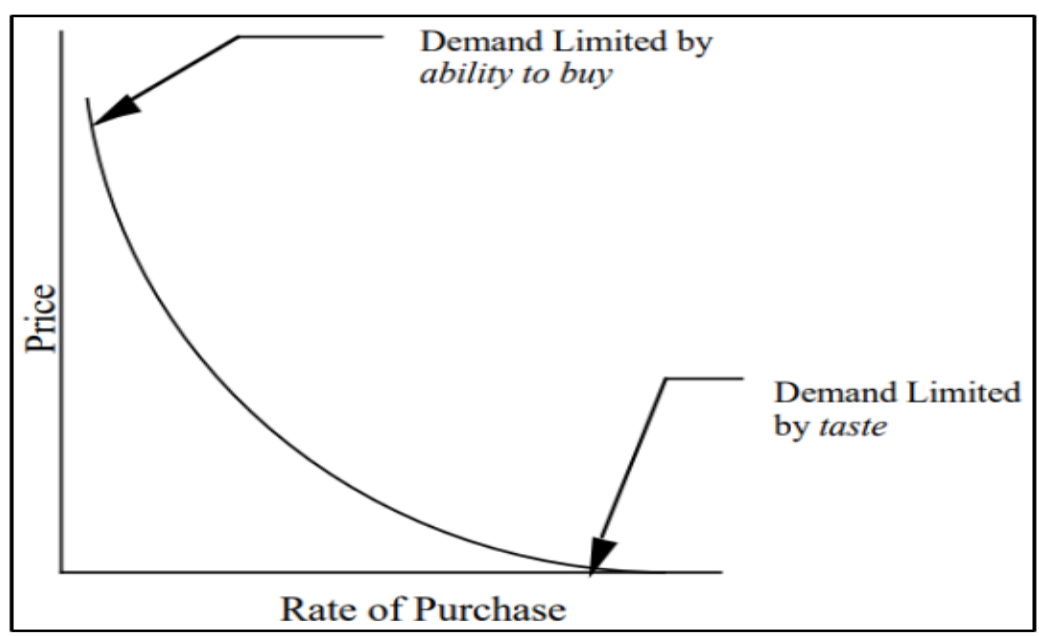

Source: Whelan \& Msefer (1996).

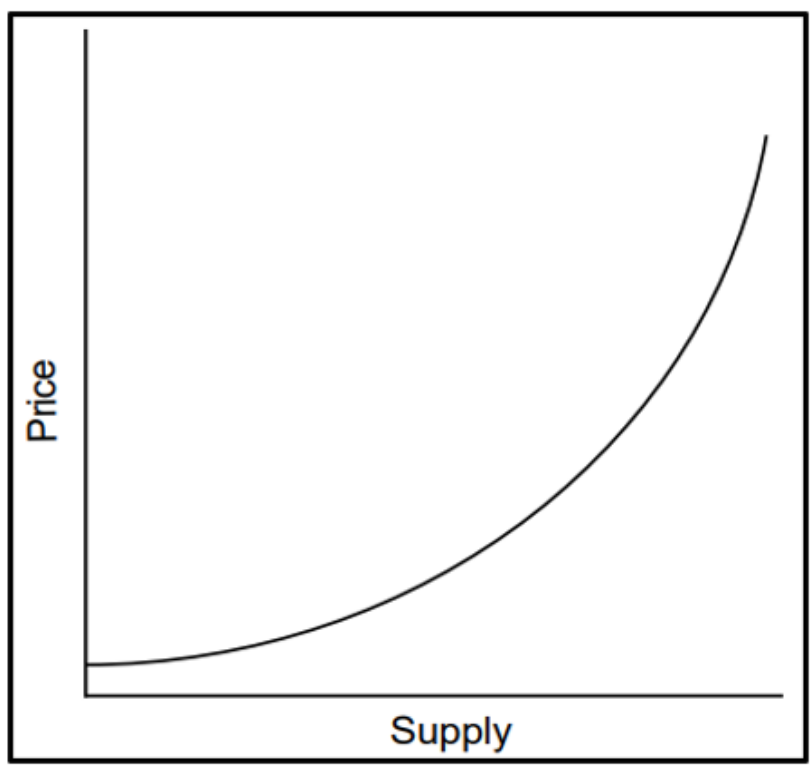

Figure 2. The point of desire.

Source: Whelan \& Msefer (1996)

As an extra illustration, the interaction between supply and demand in controlling the market is largely determined by sellers and buyers (Cannon \& Perreault, 1999). Both react in opposite ways to changes in the price of a commodity. When the ability, price and supply of sellers increase and the attention of buyers decreases, the market is clearly working (see Figure 3).

Moving on to 'microeconomic theory', an obvious example of the application of the 'law of demand' and the 'law of supply' is the level of consumption (Lee \& Keen, 2004). Within the household, they are interrelated consumptions influenced by income ability, savings, or individual willingness. The needs of each household are very diverse. Household consumption capacity also depends on educational background, age group, occupation, and social status. Those who are classified as 'rich' certainly have a source of living eligibility, while those who are 'poor' will rethink having contemporary goods or substitutes. In essence, they classify needs into three categories, namely primary needs, secondary needs, and tertiary needs. If the economy is in a stable trend, it will affect welfare, and if not, we will see a decline in welfare. Social problems, such as poverty and unemployment, are the 'old face' of transformation and development. Socioeconomic status will determine an individual's success in achieving a decent standard of living. 


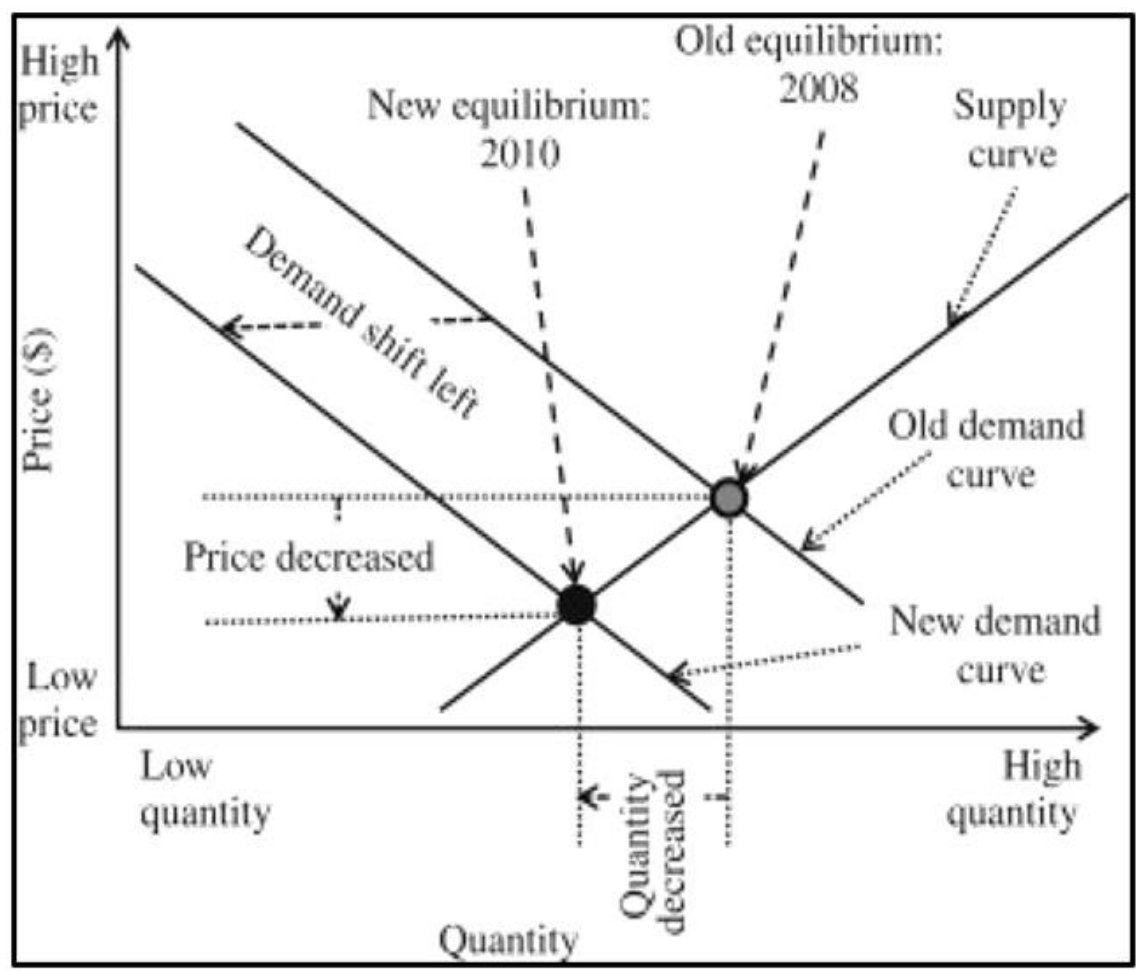

Figure 3. The points of balance of supply and demand.

Source: Hoekstra, Savenije, \& Chapagain (2001).

As an actual illustration, the 2008 financial crisis in the US created new interests that caused consumption behavior, income distribution, and household debt to increase. This explains the dynamics of the crisis (Albayrak, 2020). The paradigm has continued to flow since the 1980s, and economists assume that household consumption has decreased. Debt-based consumption and a decline in actual income followed this compensatory decline. With the help of deregulation of the financial system, the pattern that leads to increased debt and reduced savings can be reduced. However, aggregate demand and the level of consumption in the private sector remain high, so that it maintains macroeconomic stability (e.g., relatively low unemployment).

Alp \& Seven (2019) and Nelson (1988) highlight the stagnant wages of lower-middle income households. In today's era, the exploding financial crisis has become the focus of reducing credit bubbles. In the 'consumption theory' and the 'Keynesian theory', there are significant correlations between consumer behavior, household debt, and inequality (Perugini, Hölscher, \& Collie, 2016).

In principle, 'agricultural economic theory' focuses on cause and effect relationships between spatial patterns and economic decisions derived from agricultural land use. The assumption refers to farmers pursuing utility maximization in production systems (Diogo, Koomen, \& Kuhlman, 2015). Then, the framework considers land use decisions and alternatives in production (Kellerman, 1989).

Semercı et al. (2012) define the production function as a physical relationship between several inputs and outputs. Anderson et al. (1996) entered the production function into only a few input variables, while other inputs are constant (ceteris paribus) as follows:

$$
Q=f(C+L+T+R m+\ldots n)
$$

Equation 1 presents connectivity in the Cobb-Douglas function type described, where $\mathrm{Q}=$ quantity (output), $\mathrm{f}=$ function, $\mathrm{C}=$ capital, $\mathrm{L}=$ labor, $\mathrm{T}=$ technology, $\mathrm{Rm}=$ raw materials, and $\mathrm{n}=$ other supporting variables.

Through the above formulation, farmers from various countries transactional outputs on factors that support agricultural productivity implement transactionally it. The level of demand and supply significantly influenced market orientation for agricultural commodities. The relationship between consumers and producers is dominated by financial factors (Okerenta, 2005). In fact, Dwi \& Nyoman (2020) argue that the government, as a regulator, seeks to encourage and promote more local agricultural products to be absorbed by the market. They expect this enthusiasm to provide social, environmental and economic benefits for the local population (Gutman, 1959). In the theory of planned behavior (Sok, Borges, Schmidt, \& Ajzen, 2020), the buying behavior of agricultural commodities can be tested. The environment, local economic concerns, ethnocentrism of food safety, health, quality, and consumer perceptions influence consumer intentions (Petrea, 2001).

\section{METHODS}

A social experiment approach was taken in this study (such as Maat (2011); Syarifudin \& Ishak (2020); Maman, Inawati, Aminudin, \& Wastra (2017)) and a three-step-based interview technique was employed. The first step is data collection. Data were collected through the first (primary) party. Then, the second step comprised the selection of the 
number of samples based on the population summarized in the formula below. Third, a questionnaire was prepared with four answer options: high priority (4), priority (3), moderate (2), and not priority (1). The sample size is planned using the following simple mathematical calculations (e.g., (Abdullah, Gindi, Darham, \& Radam, 2015; Susanto, Siswandari, \& Rujito, 2019)):

$$
n=\frac{N}{\left[1+\left(N \times e^{2}\right)\right]}
$$

$$
\begin{array}{r}
n=\frac{658,525}{\left[1+\left(658,525 \times 0.01^{2}\right)\right]} \\
n=\frac{658,525}{[1+65.85]} \\
n=\frac{658,525}{66.85} \\
n=9,850
\end{array}
$$

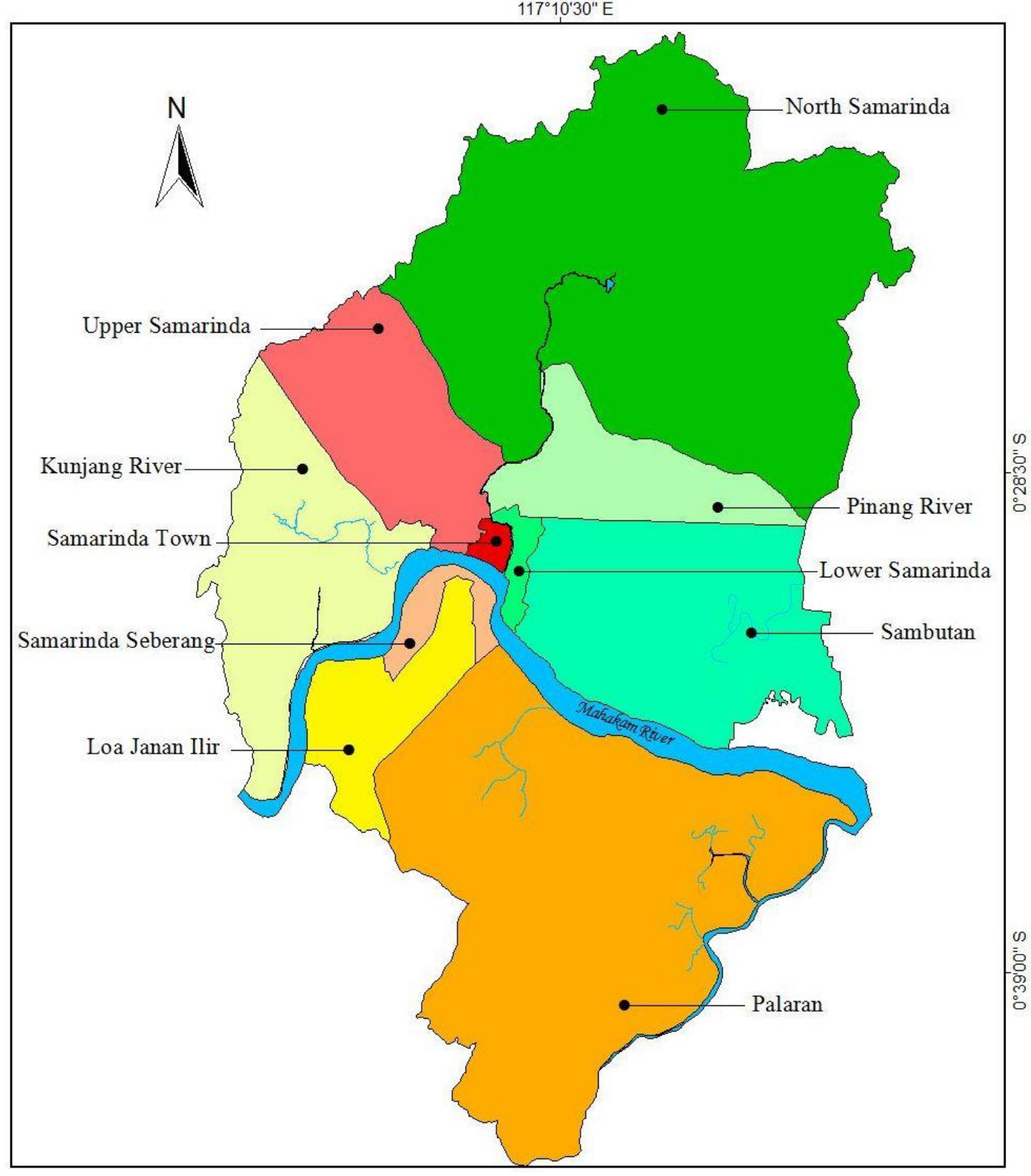

Source: Susanto et al. (2019).

Figure 4. Road map of sample distribution. 
Equations 2 to 6 formulate the identity of the sample, where $\mathrm{n}=$ sample, $\mathrm{N}=$ population, and $0.01=$ margin of error. The total population is the sum of the various age groups (15+ years). From BPS of Samarinda City (2021a), the population in Samarinda City is 827,994 , of which 658,525 are head of the family. Figure 4 displays the sample distribution model. The distribution of the sample comprises ten sub-districts in Samarinda City (64.72), including Pinang River (64.72.08), Kunjang River (64.72.06), Sambutan (64.72.07), North Samarinda (64.72.05), Samarinda Ulu (64.72). .03), Samarinda Seberang (64.72.02), Samarinda Kota (64.72.09), Samarinda Ilir (64.72.04), Palaran (64.72.01), and Loa Janan Ilir (64.72.10). Each sub-district is divided and represented by 985 respondents. Figure 4 also illustrates the coordinates of the market and the locations for buying and selling corn commodities in Samarinda City.

It carried the identification of the interview time out during December 2021. It is important to remember that the respondents reaction to the demand for corn is relevant to the celebration of the new year. To make it easier for researchers, samples were collected through Google Forms, which is promoted on social media such as WhatsApp and Facebook.

The research model was limited to the variables of consumer demand and produce supply as these two components are factors that influence market behavior. Each variable comprises four items. The demand side includes interests, traditions, tastes, and prices, while opportunity, profit, distribution, and production costs support the supply side (see Figure 5).

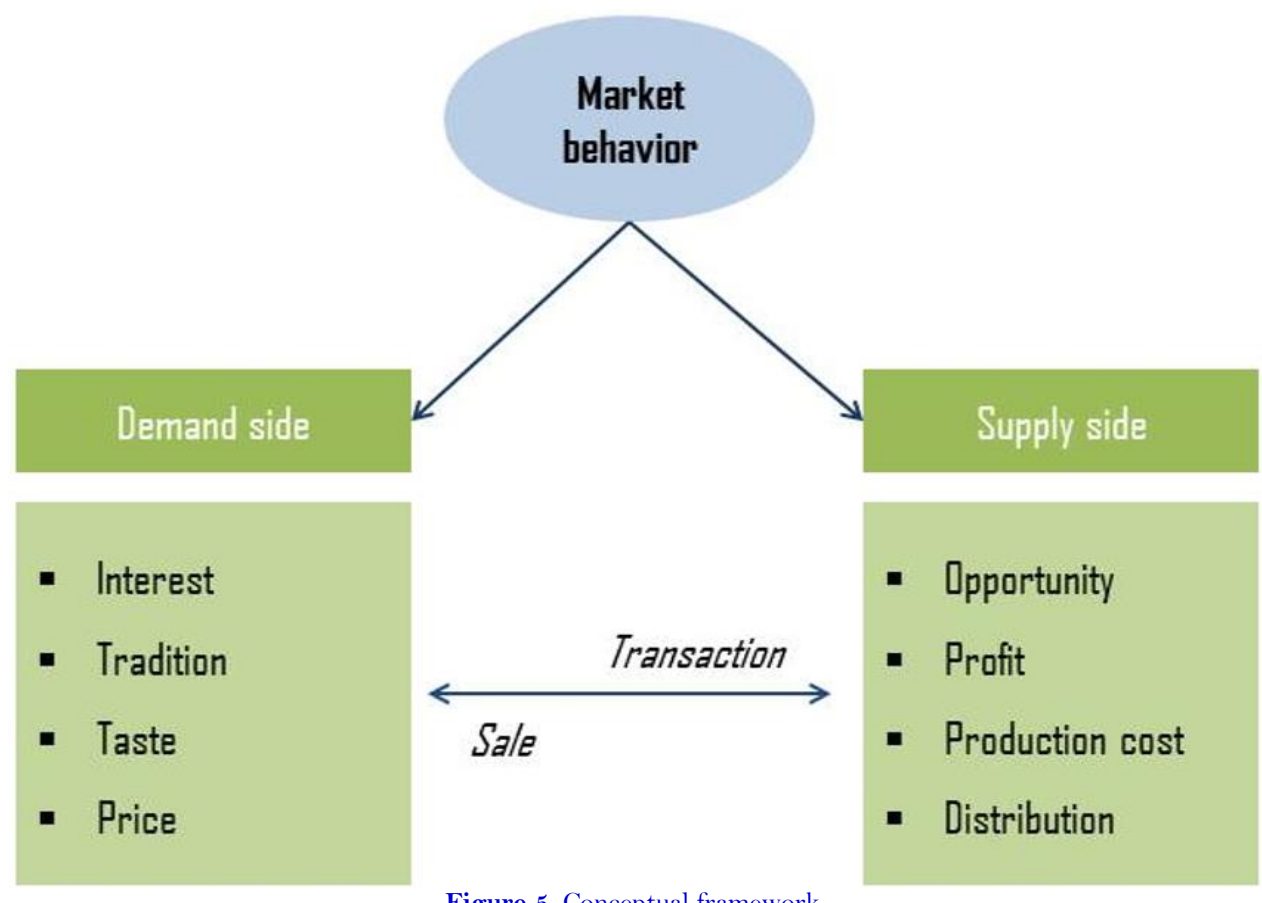

Source: Adapted from Naumova, Bilan, \& Naumova (2019); Roufagalas (1994); Li, Wang, Yin, Kull, \& Choi (2012); Xie, Gao, \& Xie (2020); Sanchez (2003).

The data processing structure was developed with the feasibility of testing correlation, reliability, and validity (e.g., De Barros Ahrens, Da Silva Lirani, \& De Francisco (2020); Dewi et al. (2021). SPSS software was used to analyze the research findings.

\section{RESULTS AND DISCUSSION}

The respondents' profiles are presented in Table 1. The sample sourced from household groups is divided into five units. Of the 9,850 household heads, 55.3 percent are male and 44.7 percent are female. Additionally, 26 percent of respondents are single, 52.7 percent are married, 18.4 percent are divorced, and the remaining 2.8 percent are widows/widowers.

Interestingly, 40 percent of respondents belong to the 16-26 age group and consume the most corn on New Year's Eve. The 49-59 age group has the fewest people, making up only 9.8 percent of respondents. When viewed based on their occupational background, the number of those classified in the labor force (already working and openly unemployed) is far higher than those classified in the non-labor force (attending school, taking care of the household, and other activities) with figures of 65.3 percent and 34.7 percent, respectively. The logical reason is that from the frequency of buying corn, as much as $3-6 \mathrm{~kg}$ or 41.5 percent, 41 percent is used and processed to become regular corn to accompany the turn of the new year celebrations.

The first model describes the value of descriptive statistics and correlations. Table 2 summarizes the output mean, standard deviation (SD), and Pearson correlation. The largest mean score is for the interest factor $(M=3.738)$ and the lowest is for the production cost factor $(M=2.667)$. For $\mathrm{SD}$, the highest is the price factor $(S D=0.735)$, while the production cost is the lowest $(S D=0.046)$. Considering that causality between factors is very important, the calculation based on SPSS estimates all of them in the positive path, although not all factors have a significant effect $(p<0.01)$. 
Table 1. Demographic of samples $(n=9,850)$

\begin{tabular}{|c|c|c|}
\hline Units & $\mathbf{N}$ & $\%$ \\
\hline \multicolumn{3}{|l|}{ Sex } \\
\hline - Female & 4.403 & 44.7 \\
\hline - Male & 5.447 & 55.3 \\
\hline \multicolumn{3}{|l|}{ Status } \\
\hline - Single & 2.565 & 26 \\
\hline - Married & 5.192 & 52.7 \\
\hline - Divorced & 1.816 & 18.4 \\
\hline - Widow/widower & 277 & 2.8 \\
\hline \multicolumn{3}{|l|}{ Age group } \\
\hline - 16-26 years & 3.940 & 40 \\
\hline - $\quad 27-37$ years & 1.189 & 12.1 \\
\hline - $\quad 38-48$ years & 2.258 & 22.9 \\
\hline - $\quad 49-59$ years & 961 & 9.8 \\
\hline - $60+$ years & 1.502 & 15.2 \\
\hline \multicolumn{3}{|l|}{ Main activity } \\
\hline - Economically active & 6.431 & 65.3 \\
\hline - Economically inactive & 3.419 & 34.7 \\
\hline \multicolumn{3}{|l|}{ Purchase frequency } \\
\hline - $\quad 2 \mathrm{~kg}$ & 1.001 & 10.2 \\
\hline - $\quad 3-6 \mathrm{~kg}$ & 4.086 & 41.5 \\
\hline - $\quad 7-10 \mathrm{~kg}$ & 3.846 & 39 \\
\hline - $11+\mathrm{kg}$ & 917 & 9.3 \\
\hline \multicolumn{3}{|l|}{ Diversification of corn } \\
\hline - $\quad$ Fried corn & 2.594 & 26.3 \\
\hline - Roasted corn & 3.217 & 32.7 \\
\hline - $\quad$ Boiled corn & 4.039 & 41 \\
\hline
\end{tabular}

Table 2. Descriptive statistics and correlation matrix.

\begin{tabular}{|c|c|c|c|c|c|c|c|c|c|c|}
\hline Items & Mean & SD & 1 & 2 & 3 & 4 & 5 & 6 & 7 & 8 \\
\hline Interest & 3.738 & 0.114 & 1 & $\begin{array}{c}0.011 \\
(0.473)^{*}\end{array}$ & $\begin{array}{c}0.071 \\
(0.321)^{*}\end{array}$ & $\begin{array}{c}0.305 \\
(0.021)^{*}\end{array}$ & $\begin{array}{c}0.167 \\
(0.136)^{*}\end{array}$ & $\begin{array}{c}0.056 \\
(0.358)^{*}\end{array}$ & $\begin{array}{c}0.064 \\
(0.337)^{*}\end{array}$ & $\begin{array}{c}0.429 \\
(0.000)^{*}\end{array}$ \\
\hline Tradition & 3.597 & 0.545 & $\begin{array}{c}0.011 \\
(0.473)^{*}\end{array}$ & 1 & $\begin{array}{c}0.574 \\
(0.000)^{*}\end{array}$ & $\begin{array}{c}0.099 \\
(0.258)^{*}\end{array}$ & $\begin{array}{c}0.136 \\
(0.186)^{*}\end{array}$ & $\begin{array}{c}0.543 \\
(0.000)^{*}\end{array}$ & $\begin{array}{c}0.325 \\
(0.015)^{*}\end{array}$ & $\begin{array}{c}0.201 \\
(0.391)^{*}\end{array}$ \\
\hline Taste & 3.602 & 0.396 & $\begin{array}{c}0.071 \\
(0.321)^{*}\end{array}$ & $\begin{array}{c}0.574 \\
(0.000)^{*}\end{array}$ & 1 & $\begin{array}{c}0.174 \\
(0.126)^{*}\end{array}$ & $\begin{array}{c}0.092 \\
(0.275)^{*}\end{array}$ & $\begin{array}{c}0.991 \\
(0.000)^{*}\end{array}$ & $\begin{array}{c}0.122 \\
(0.212)^{*}\end{array}$ & $\begin{array}{c}0.656 \\
(0.157)^{*}\end{array}$ \\
\hline Price & 3.713 & 0.735 & $\begin{array}{c}0.305 \\
(0.021)^{*}\end{array}$ & $\begin{array}{c}0.099 \\
(0.258)^{*}\end{array}$ & $\begin{array}{c}0.174 \\
(0.126)^{*}\end{array}$ & 1 & $\begin{array}{c}0.281 \\
(0.031)^{*}\end{array}$ & $\begin{array}{c}0.166 \\
(0.137)^{*}\end{array}$ & $\begin{array}{c}0.300 \\
(0.023)^{*}\end{array}$ & $\begin{array}{c}0.478 \\
(0.000)^{*}\end{array}$ \\
\hline Opportunity & 3.498 & 0.112 & $\begin{array}{c}0.167 \\
(0.136)^{*}\end{array}$ & $\begin{array}{c}0.136 \\
(0.186)^{*}\end{array}$ & $\begin{array}{c}0.092 \\
(0.275)^{*}\end{array}$ & $\begin{array}{c}0.281 \\
(0.031)^{*}\end{array}$ & 1 & $\begin{array}{c}0.103 \\
(0.251)^{*}\end{array}$ & $\begin{array}{c}0.437 \\
(0.001)^{*}\end{array}$ & $\begin{array}{c}0.513 \\
(0.417)^{*}\end{array}$ \\
\hline Profit & 3.606 & 0.287 & $\begin{array}{c}0.056 \\
(0.358)^{*}\end{array}$ & $\begin{array}{c}0.543 \\
(0.000)^{*}\end{array}$ & $\begin{array}{c}0.981 \\
(0.000)^{*}\end{array}$ & $\begin{array}{c}0.166 \\
(0.137)^{*}\end{array}$ & $\begin{array}{c}0.103 \\
(0.251)^{*}\end{array}$ & 1 & $\begin{array}{c}0.098 \\
(0.261)^{*}\end{array}$ & $\begin{array}{c}0.772 \\
(0.106)^{*}\end{array}$ \\
\hline $\begin{array}{l}\text { Production } \\
\text { Cost }\end{array}$ & 2.667 & 0.046 & $\begin{array}{c}0.064 \\
(0.337)^{*}\end{array}$ & $\begin{array}{c}0.325 \\
(0.015)^{*}\end{array}$ & $\begin{array}{c}0.122 \\
(0.212)^{*}\end{array}$ & $\begin{array}{c}0.300 \\
(0.023)^{*}\end{array}$ & $\begin{array}{c}0.437 \\
(0.001)^{*}\end{array}$ & $\begin{array}{c}0.098 \\
(0.261)^{*}\end{array}$ & 1 & $\begin{array}{c}0.180 \\
(0.097)^{*}\end{array}$ \\
\hline Distribution & 3.574 & 0.204 & $\begin{array}{c}0.272 \\
(0.013)^{*}\end{array}$ & $\begin{array}{c}0.166 \\
(0.032)^{*}\end{array}$ & $\begin{array}{c}0.293 \\
(0.145)^{*}\end{array}$ & $\begin{array}{c}0.317 \\
(0.289)^{*}\end{array}$ & $\begin{array}{c}0.345 \\
(0.167)^{*}\end{array}$ & $\begin{array}{c}0.470 \\
(0.047)^{*}\end{array}$ & $\begin{array}{c}0.155 \\
(0.000)^{*}\end{array}$ & 1 \\
\hline
\end{tabular}

Source: SPSS output. Note: ${ }^{*}$ p-value $<0.01$.

The results of further investigations also confirmed the two-way relationship between interest and distribution $(C=0.429$ and $p=0.000)$, tradition and taste $(C=0.574$ and $p=0.000)$, taste and profit $(C=0.991$ and $p=0.000)$, price and distribution $(C=0.478$ and $p=0.000)$, opportunity and production cost $(C=0.437$ and $p=0.001)$, profit and taste $(C=0.981$ and $p=0.000)$, production cost and opportunity $(C=0.437$ and $p=0.001)$, and distribution and production cost $(C=0.155$ and $p=0.000)$. Production costs and distribution are considered the most dominant of all the factors.

The second parameter is validity testing, as measured by confirmatory factor analysis (CFA). The KaiserMeyer-Olkin measure of sampling (KMO-MSA) is an index of the distance comparison between the correlation 
coefficient and its partial correlation coefficient. If the sum of the squares of the partial correlation coefficients from all pairs of variables is small compared to the sum of the squares of the correlation coefficients, it will produce a KMO-MSA value close to 1. The KMO-MSA gain is sufficient if it is < 0.5 (Hair, Black, Babin, Enderson, \& Tatham, 2006). Another projection from Bartlett's test shows that there is a sufficient correlation between the variables to apply, provided that the p-value is < 0.01 (e.g., Melati (2018)).

Assumptions in construct validity are based on Bartlett's test of sphericity, and content validity is determined by the KMO test. Table 3 explains that the achievement of the correlation between indicators for the consumer demand variable is high $(K M O=0.632$ and Bartlett's test $=0.000)$, so the factor analysis process is workable allowing the analysis to continue.

\begin{tabular}{l|c}
\multicolumn{2}{c}{ Table 3. Construct validity and content validity in the first element. } \\
\hline Measurement & Score \\
\hline KMO-MSA & 0.632 \\
\hline Approx. Chi-square & 315.11 \\
\hline Df. & 90849 \\
\hline Prob. & 0.000 \\
\hline Source: SPSS outputt
\end{tabular}

Table 4. Construct validity and content validity in the second element.

\begin{tabular}{l|c}
\hline Measurement & Score \\
\hline KMO-MSA & 0.580 \\
\hline Approx. Chi-square & 207.69 \\
\hline Df. & 90849 \\
\hline Prob. & 0.000 \\
\hline Source: SPSS output.
\end{tabular}

Overall, Bartlett's test resulted in a p-value of 0.000 and a KMO-MSA of 0.580. This shows that both meet the requirements because the KMO-MSA has a value of $>0.5$ and a significance of $<0.01$, so it is prioritized for the next process (see Table 4).

In the third session, identification of the assumption that must be met is reliability. We packed reliability testing with Cronbach's alpha (CA) coefficients. Classification of Cronbach's alpha is possible if the coefficient value is $>0.7$, which means that the reliability is met. It also makes sense if the coefficient is $>0.8$, which suggests that all items are reliable and all tests are internally consistent because they have strong reliability (Hoekstra, Vugteveen, Warrens, \& Kruyen, 2018; Peterson, 1994). Table 5 summarizes the coefficient gains of Cronbach's alpha.

It can be interpreted that if the alpha coefficient is low, it is possible that one or more indicators is not reliable, so it makes sense to investigate with a per item analysis procedure. This test is a continuation of the previous series to determine if certain indicators do not meet the requirements. Through this process, unreliable indicators can be discarded so that other alphas can further support their value (Tavakol \& Dennick, 2011).

Table 5. Cronbach's alpha for all indicators.

\begin{tabular}{l|c|c}
\hline Items & CA & Remark \\
\hline Interest & 0.587 & Moderate reliability \\
\hline Tradition & 0.749 & High reliability \\
\hline Taste & 0.687 & Moderate reliability \\
\hline Price & 0.682 & Moderate reliability \\
\hline Opportunity & 0.705 & High reliability \\
\hline Profit & 0.934 & Almost perfect reliability \\
\hline Production cost & 0.820 & High reliability \\
\hline Distribution & 0.717 & High reliability \\
\hline Source: SPSS output. & &
\end{tabular}

The advancement of people's perspectives and ways of thinking determine what food is worth consuming at an affordable price. They are drawn towards selecting products with relatively cheap prices but without neglecting practicality and nutritional composition. The other side is the level of need that is increasing along with accessibility. The importance of corn is a signal to farmers that this type of plant is also easy to grow from narrow land, open space, in all seasons with sufficient light intensity, soil fertility level, and rainfall level. With the harvest period in intervals of 2-3 months, it is possible for corn farmers to achieve maximum productivity. They will certainly see a significant market demand, especially towards the end of the year. Each period, the consumption of corn soars sharply, so preparation for farming starts in September or October.

In the context of economic development and food security, the agricultural industry has played a key role for decades (Zyl, 1989). Directly, the best options are in rural areas, where a large part of the world's population also depends on this sector for their livelihoods (Udemezue \& Osegbue, 2018). As the migration of people to cities and the world's population explodes, it has a systematic impact on the proportion of growth in food production.

Martin, Groenewegen, \& Pidgeon (1980) found that the uniqueness of market characteristics highly depends on the specifics of corn in Southwestern Ontario (Canada) where corn farmers saw a tremendous opportunity to create 
welfare value. Global corn prices influenced the retail of corn-based products in the manufacturing sector (Rattray, 2012). This is a determinant of price policy by major food companies. High global corn prices have affected final retail and consumer products. Even though the market conditions for agriculture and food companies were fluctuating, they corn farmers could still benefit. Sibanda, Mushunje, \& Mutengwa (2016) highlight valuable steps adopted by small-scale maize farmers in OR Tambo and Amatole (Eastern Cape, South Africa). Samples from households were asked for their response to maize, and the findings confirm that planning and decision-making in the maize market highly depend on seed availability, farmer perceptions, land area, income, access to credit, and access to extension services. The application of superior seeds and the absorption of corn commodities has played an important role in the productivity of corn farmers.

During the period from 1948-1970, the supply of maize acreage in the US underwent a significant change due to the government's price intervention and acreage control program. Empirical analysis examines area restrictions, transfers, support, and lending rates for maize farmers. Houck \& Ryan (1972) suggested that policy variables should be selected and applied to maize as part of government priorities.

Production and land management decisions strongly influenced land conservation and crop. Farmers in the Liandaowan area (Northeast China) make decisions based on motivation as a key factor in implementing government policies. Most of the farmers there insist on growing maize despite facing various obstacles, such as striking comparative advantage, farmer preferences, age and education, low temperatures, drought, technical help, low income, and availability of machinery. The experimental results obtained by Liu, Zhang, Liu, \& He (2019) emphasized the need for promotions to adjust for corn diversity because the level of demand was stable.

The theoretical justification for these findings is in line with the investigations of Mišečka, Ciaian, Rajčániová, \& Pokrivčák (2019), who emphasized that agricultural commodity prices are driving consumer awareness. On an international scale, behavior towards agricultural products, such as corn, is permanently and causally connected to the demand factor, and the corn prices confirm both relationships.

Other aspects, such as campaigns against 'green consumption', brands, channels, prices and marketing strategies, can stimulate agricultural products in Wuhan (China). Yi (2017) revealed that the safety of people's lives there for agricultural products depends not only on stability but also on sustainable agricultural development. Farm household investigated their perceptions and levels of knowledge based on purchasing behavior, work background, income level, region, age, and gender.

The causality highlighted by Gao, Huang, Zhong, Chen, \& Lu (2013) and Horská, Petrilák, Šedík, \& Nagyová (2020) regarding the sale of local agricultural products is not only influenced by the behavior of farmers, but also by the driving forces of the market. In China, in 16 villages in Anhui, Jiangsu and Shanghai, households earn higher profits. They see economic developments in the agricultural market, thus shifting from food crops to cash crops. Aspects of capital and production costs are the more dominant input factors, where they know that if they want to achieve a large output, then the production input becomes a big investment. In this way, agricultural products gain market enthusiasm because the selling price is more significant than government subsidies. Market sales orientation supported the independence of agricultural households based on product quality improvement strategies (Hunt, 2007). Unlike the case with local farmers in Slovakia, the sales of agricultural products depend on the supply chain. This was driven by a short distribution route so that the product can go directly to consumers. Customer loyalty is motivated by locality, freshness, and quality factors. That way, the marketing approach is a surefire technique to save time, cost, and effort.

\section{CONCLUSION}

This study analyzed the influence of the demand and supply sides on the behavior of the corn market in Samarinda City, Indonesia, and it was found that the two are closely related as both consumers and producers respond to each other based on the quantity of corn. Towards the end of the year, demand from consumers increased in line with the supply of producers. However, the supply side variable determines the market the most because the two indicators (production cost and distribution) have the highest coefficients with a positive path.

This study contributes to the theoretical aspect. Extension services to seasonal corn farmers in Samarinda City, are not only based on certain moments (such as New Year's celebrations and festivals), but also follow market patterns that follow demand trends. For the future, there is a need for policies on distribution, training, extension, knowledge, and promotion services for corn farmers. We expect the implications for industry practitioners and academics to attract attention to highlight and expand knowledge regarding the factors that influence market behavior for corn besides the supply and demand factors.

The limitation of this study is in the variables used. The sample range and observation period can be expanded to produce more extensive findings. In order to support socioeconomic sustainability in agriculture, these findings require scientific references and foundations based on a more constructive scale.

Funding: This study received no specific financial support.

Competing Interests: The authors declare that they have no competing interests.

Authors' Contributions: All authors contributed equally to the conception and design of the study.

Views and opinions expressed in this study are those of the authors views; the Asian Journal of Agriculture and Rural Development shall not be responsible or answerable for any loss, damage, or liability, etc. caused in relation to/arising out of the use of the content. 


\section{REFERENCES}

Abdullah, A. M., Gindi, A. A., Darham, S., \& Radam, A. (2015). Farmers attitudes toward risks in paddy production of north-West Selangor integrated agricultural development area (IADA), Malaysia. Asian Journal of Agriculture and rural Development, 5(7), 158-166.

Aday, S., \& Aday, M. S. (2020). Impact of Covid-19 on the food supply chain. Food Quality and Safety, 4(4), 167-180.Available at: https://doi.org/10.1093/fqsafe/fyaa024.

Ai-Hua, T. (2012). Factors influencing price of agricultural products and stability countermeasures. Asian Agricultural Research, 4(4), 17-43.Available at: https://doi.org/10.22004/ag.econ.137216.

Alam, M. M., \& Uddin, M. G. S. (2009). Relationship between interest rate and stock price: Empirical evidence from developed and developing countries. International Journal of Business and Management, 4(3), 43-51.Available at: https://doi.org/10.5539/ijbm.v4n3p43.

Albayrak, Ö. (2020). Household consumption, household indebtedness, and inequality in Turkey: A microeconometric analysis. Working Paper No. 954.

Alp, E., \& Seven, Ü. (2019). The dynamics of household final consumption: The role of wealth channel. Central Bank Revierw, 19(1), 21-32.Available at: https://doi.org/10.1016/j.cbrev.2019.03.002.

Anderson, D. P., Chaisantikulawat, T., Guan, A. T. K., Kebbeh, M., Lin, N., \& Shumway, C. R. (1996). Choice of functional form for agricultural production analysis. Review of Agricultural Economics, 18(2), 223-231.Available at https://doi.org/10.2307/1349434.

Arifin, B. (2013). On the competitiveness and sustainability of the Indonesian agricultural export commodities. ASEAN Journal of Economics, Management and Accounting, 1(1), 81-100.

Aya, R. (1979). Theories of revolution reconsidered. Theory and Society, 8(1), 39-99.Available at: https://doi.org/10.1007/BFo0156400.

BPS of Samarinda City. (2021a). Samarinda city people's welfare indicator 2020/202 1 [In English: Samarinda city people's welfare indicator 2020/2021]. Retrieved from https://samarindakota.bps.go.id/publication/2021/11/23/369dd5d89366189a6de88124/indikator-kesejahteraanrakyat-kota-samarinda-2020-202 1.html.

BPS of Samarinda City. (2021b). Samarinda city in figures 2021 [in English: Samarinda Municipality in Figures 2021]. Retrieved from https://samarindakota.bps.go.id/publication/2021/02/26/fcfcfc591d2a8840ca6cacbb/kota-samarinda-dalamangka-202 1.html.

Cannon, J. P., \& Perreault, W. D. (1999). Buyer-seller relationships in business markets. Journal of Marketing Research, 36(4), 439460.Available at: https://doi.org/10.1177/002224379903600404.

Darma, S., Wijaya, A., \& Darma, D. C. (2020). Different tests for the existence of agricultural cooperatives in Indonesia: Before and after Covid-19. Asia Life Sciences, 10(3), 615-628.

Darma, S., Maria, S., Lestari, D., \& Darma, D. C. (2020). An agroforestry consortium: A multiderminant in instituting an agrisilviculture system to improve welfare. Virtual Economics, 3(1), 95-111.Available at: https://doi.org/10.34021/ve.2020.03.01(5).

Davidson, L. (1999). Reality and economic theory. Journal of Post Keynesian Economics, 18(4), 479-508.Available at: https://doi.org/10.1007/978-1-349-14991-9_1.

De Barros Ahrens, R., Da Silva Lirani, L., \& De Francisco, A. C. (2020). Construct validity and reliability of the work environment assessment instrument WE-10. International Journal of Environmental Research and Public Health, 17(20), 7364.Available at: https://doi.org/10.3390/ijerph 17207364 .

Dewi, I. G. A., Riana, I. G., Kasuma, J., McGuinness, E., Maria, S., \& Darma, D. C. (2021). Predicting organizational citizenship behavior through psychological ownership and job satisfaction in four-star hotels. GeoJournal of Tourism and Geosites, 37(3), 807-813.Available at: https://doi.org/10.30892/gtg.37310-712.

Diogo, V., Koomen, E., \& Kuhlman, T. (2015). An economic theory-based explanatory model of agricultural land-use patterns: The Netherlands as a case study. Agricultural Systems, 139, 1-16.Available at: https://doi.org/10.1016/j.agsy.2015.06.002.

Dwi, P. I., \& Nyoman, Y. N. (2020). Factors affecting the purchase of local agricultural commodities. Russian Journal of Agricultural and Socio-Economic Sciences, 101(5), 47-57.Available at: https://doi.org/10.18551/rjoas.2020-05.05.

Farandy, A. R. (2020). Analyzing factors affecting Indonesian food price inflation. Journal of Economics and Development, 28(1), 6576.Available at: https://doi.org/10.14203/JEP.28.1.2020.65-76.

Ferrero, R., Mauricio, L., \& Gonzalez-Andujar, J. L. (2014). Spatio-temporal dynamics of maize yield water constraints under climate change in Spain. PLoS One, 9(5), e98220.Available at: https://doi.org/10.1371/journal.pone.0098220.

Gao, S., Huang, X., Zhong, T., Chen, Z., \& Lu, X. (2013). Effect of farmers' behavior on agricultural production benefits: An empirical analysis based on market driving force in China. Journal of Food, Agriculture \& Environment, 11(2), 535-539.

Gutman, G. O. (1959). Some aspects of the supply of agricultural products. Australian Journal of Agricultural Economics, 3(1), 1123.Available at: https://doi.org/10.1111/j.1467-8489.1959.tboo249.x.

Hair, J. F., Black, W. C., Babin, B. J., Enderson, R. E., \& Tatham, R. L. (2006). Mutivariate data analysis (5th ed.). Upper Saddle River: Pearson Education.

Harahap, L. K., Amanah, D., Harahap, D. A., \& Jubaidah, S. (2019). Factors affecting consumer demand on orange fruit in Pantai Buaya, Langkat, Indonesia. International Journal of Economics, Business and Management Research, 3(11), 113-125.

Haugen, R. A., Talmor, E., \& Torous, W. N. (1991). The effect of volatility changes on the level of stock prices and subsequent expected returns. The Journal of Finance, 46(3), 985-1007.Available at: https://doi.org/10.1111/j.15406261.1991.tbo3774.x.

Hoekstra, A., Savenije, H., \& Chapagain, A. (2001). An integrated approach towards assessing the value of water: A case study on the Zambezi Basin. Integrated Assessment, 2(4), 199-208.Available at: https://doi.org/10.1023/A:1013368524528.

Hoekstra, R., Vugteveen, J., Warrens, M. J., \& Kruyen, P. M. (2018). An empirical analysis of alleged misunderstandings of coefficient alpha. International Journal of Social Research Methodology, 22(4), 351-364.Available at: https://doi.org/10.1080/13645579.2018.1547523.

Horská, E., Petril'ák, M., Šedík, P., \& Nagyová, L. (2020). Factors influencing the sale of local products through short supply chains: A case of family dairy farms in Slovakia. Sustainability, 12(20), 8499.Available at: https://doi.org/10.3390/su12208499. 
Houck, J. P., \& Ryan, M. E. (1972). Supply analysis for corn in the United States: The impact of changing government programs. American Journal of Agricultural Economics, 54(2), 184-191.Available at: https://doi.org/10.2307/1238700.

Hovhannisyan, V., Kondaridze, M., Bastian, C., \& Shanoyan, A. (2020). Empirical evidence of changing food demand and consumer preferences in Russia. Journal of Agricultural and Applied Economics, 52(3), 480-501.Available at: https://doi.org/10.1017/aae.2020.13.

Humphrey, T. M. (1992). Marshallian cross diagrams and their uses before Alfred Marshall: The origins of supply and demand geometry. Economic Review, 78(Mar), 3-23.

Hunt, A. (2007). Consumer interactions and influences on farmers' market vendors. Renewable Agriculture and Food Systems, 22(1), 54-66.Available at: https://doi.org/10.1017/S1742170507001597.

Indriastuti, H., Kasuma, J., Zainurrosalamia, S., Darma, D. C., \& Sawangchai, A. (2020). Achieving marketing performance through acculturative product advantages: The case of sarong Samarinda. Asian Journal of Business and Accounting, 13(1), 241261.Available at: https://doi.org/10.22452/ajba.vol13no1.9.

Inoua, S. M., \& Smith, V. L. (2020). The classical theory of supply and demand. ESI Working Paper No. 20-11.

Jehle, G. A., \& Reny, P. J. (2011). Advanced microeconomic theory (3rd ed.). Harlow: Pearson Education Limited.

Kellerman, A. (1989). Agricultural location theory 1: basic models. Environment and Planning A: Economy and Space, 21(10), 13811396.Available at: https://doi.org/10.1068/a211381.

Lee, F. S., \& Keen, S. (2004). The incoherent emperor: A heterodox critique of neoclassical microeconomic theory. Review of Social Economy, 62(2), 169-199.Available at: https://doi.org/10.1080/00346760410001684433.

Li, H., Wang, Y., Yin, R., Kull, T. J., \& Choi, T. Y. (2012). Target pricing: Demand-side versus supply-side approaches. International Journal of Production Economics, 136(1), 172-184.Available at: https://doi.org/10.1016/j.ijpe.2011.10.002.

Liu, S., Zhang, P., Liu, W., \& He, X. (2019). Key factors affecting farmers' choice of corn reduction under the China's new agriculture policy in the 'Liandaowan' areas, Northeast China. Chinese Geographical Science, 29(12), 1039-1051.Available at: https://doi.org/10.1007/s11769-019-1078-3.

Maat, H. (2011). The history and future of agricultural experiments. NJAS - Wageningen Journal of Life Sciences, 57(3-4), 187195.Available at: https://doi.org/10.1016/j.njas.2010.11.001.

MacDonald, J. M. (2000). Demand, information, and competition: Why do food prices fall at seasonal demand peaks? The Journal of Industrial Economics, 48(1), 27-45.Available at: https://doi.org/10.1111/1467-6451.00111.

Maman, U., Inawati, I., Aminudin, I., \& Wastra, A. R. (2017). The need of tailor made agribusiness farmer field school to develop entrepreneurship: The experience from paddy seed growers in Indonesia context. Journal of Engineering and Applied Sciences, 12(10), 2676-2681.Available at: https://doi.org/10.3923/jeasci.2017.2676.2681.

Martin, L., Groenewegen, J. L., \& Pidgeon, E. (1980). Factors affecting corn basis in Southwestern Ontario. American Journal of Agricultural Economics, 62(1), 107-1 12.Available at: https://doi.org/10.2307/1239477.

Mazurek, J., García, C. F., \& Rico, C. P. (2019). The law of demand and the loss of confidence effect: An experimental study. Heliyon, 5(11), e02685.Available at: https://doi.org/10.1016/j.heliyon.2019.e02685.

Melati, R. (2018). The effect of perceptions about health product advertorials in newspapers on consumer attitudes. Journal of Science and Health, 1(10), 561-569.Available at: https://doi.org/10.25026/jsk.v1i10.91.

Milgrom, P., \& Strulovici, B. (2006). Concepts and properties of substitute goods. Economics Papers 2006-W02. Economics Group, Nuffield College, University of Oxford. Retrieved from: https://www.researchgate.net/publication/5201153_Concepts_and_Properties_of_Substitute_Goods.

Mišečka, T., Ciaian, P., Rajčániová, M., \& Pokrivčák, J. (2019). In search of attention in agricultural commodity markets. Economics Letters, 184, 108668.Available at: https://doi.org/10.1016/j.econlet.2019.108668.

Moss, L. S. (1974). Mountifort Longfield's supply-and-demand theory of price and its place in the development of British economic theory. History of Political Economy, 6(4), 405-434.Available at: https://doi.org/10.1215/00182702-6-4-405.

Naumova, O., Bilan, S., \& Naumova, M. (2019). Luxury consumers' behavior: A cross-cultural aspect. Innovative Marketing, 15(4), 1-13.Available at: https://doi.org/10.21511/im.15(4).2019.01.

Nelson, J. A. (1988). Household economies of scale in consumption: Theory and evidence. Econometrica, 56(6), 1301-1314.Available at: https://doi.org/10.2307/1913099.

Nuss, E. T., \& Tanumihardjo, S. A. (2010). Maize: A paramount staple crop in the context of global nutrition. Comprehensive Reviews in Food Science and Food Safety, 9(4), 417-436.Available at: https://doi.org/10.1111/j.1541-4337.2010.00117.x.

Okerenta, S. J. (2005). Factors affecting demand and supply of agricultural credit to farmers in Rivers State of Nigeria. Journal of Agriculture, Forestry and the Social Sciences, 3(1), 26-34.Available at: https://doi.org/10.4314/joafss.v3i1.33702.

Parro, F. (2019). Understanding the supply and demand forces behind the fall and rise in the us skill premium. Macroeconomic Dynamics, 23(6), 2191-2220.Available at: https://doi.org/10.1017/S1365100517000669.

Paul, S. C., Jahan, N., Nandi, A. K., \& Rahman, A. (2021). Nexus between FDI, agriculture, and rural development: Evidence from Asian countries. Asian Journal of Agriculture and Rural Development, 11(4), 311-319.Available at: https://doi.org/10.18488/journal.ajard.2021.114.311.319.

Perugini, C., Hölscher, J., \& Collie, S. (2016). Inequality, credit and financial crises. Cambridge Journal of Economics, 40(1), 227257.Available at: https://doi.org/10.1093/cje/beu075.

Peterson, R. A. (1994). A meta-analysis of Cronbach's coefficient alpha. Journal of Consumer Research, 21(2), 381-391.Available at: https://doi.org/10.1086/209405.

Petrea, R. E. (2001). The theory of planned behavior: Use and application in targeting agricultural safety and health interventions. Journal of Agricultural Safety and Health, 7(1), 7-19.Available at: https://doi.org/10.13031/2013.2603.

Purcell, W. D., \& Lusk, J. (2003). Demand for red meats: Principles, research evidence, and issues the veterinary clinics of North America. Food Animal Practice, 19(2), 463-468.Available at: https://doi.org/10.1016/s0749-0720(03)00027-6.

Rattray, J. (2012). The implications of the increasing global demand for corn. UW-L Journal of Undergraduate Research, 15(2012), 1-10.

Resnik, D. B., \& Elliott, K. C. (2016). The ethical challenges of socially responsible science. Accountability in Research, 23(1), 3146.Available at: https://doi.org/10.1080/08989621.2014.1002608.

Rianti, A., Novenia, A. E., Christopher, A., Lestari, D., \& Parassih, E. K. (2018). Ketupat as traditional food of Indonesian culture. Journal of Ethnic Foods, 5(1), 4-9.Available at: https://doi.org/10.1016/j.jef.2018.01.001. 
Rosas-Castor, J. M., Guzmán-Mar, J. L., Hernández-Ramírez, A., Garza-González, M. T., \& Hinojosa-Reyes, L. (2014). Arsenic accumulation in maize crop (Zea mays): A review. Science of the Total Environment, 488-489C(1), 176-187.Available at: https://doi.org/10.1016/j.scitotenv.2014.04.075.

Roufagalas, J. (1994). Price rigidity: An exploration of the demand side. Managerial and Decision Economics, 15(1), 87-94.Available at: https://doi.org/10.1002/mde.4090150110.

Safiullin, L. N., Oduntsova, J. L., \& Safiullin, N. Z. (2015). The theory of demand in the conditions of heterogeneity of goods and consumers. Procedia Economics and Finance, 24, 288-295.Available at: https://doi.org/10.1016/S22 12-5671(15)00662-0.

Sanchez, R. (2003). Integrating transaction costs theory and real options theory. Managerial and Decision Economics, 24(4), 267282.Available at: https://doi.org/10.1002/mde.1124.

Sandhu, H., Scialabba, N. E., Warner, C., Behzadnejad, F., Keohane, K., Houston, R., \& Fujiwara, D. (2020). Evaluating the holistic costs and benefits of corn production systems in Minnesota, US. Scientific Reports, 1O(1), 3922.Available at: https://doi.org/10.1038/s41598-020-60826-5.

Schmidt, L. E. (1991). The commercialization of the calendar: American holidays and the culture of consumption, 1870-1930. Journal of American History, 78(3), 887-916.Available at: https://doi.org/10.2307/2078795.

Semercı, A., Mazid, A., Amegbeto, K., Keser, M., Morgounov, A., Peker, K., \& Kan, M. (2012). The production functions of wheat production in Turkey. Bulgarian Journal of Agricultural Science, 18(2), 240-253.

Sibanda, M., Mushunje, A., \& Mutengwa, C. S. (2016). Factors influencing the demand for improved maize open pollinated varieties (OPVs) by smallholder farmers in the Eastern Cape Province, South Africa. Journal of Cereals and Oilseeds, 7(2), 14-26.Available at: https://doi.org/10.5897/JCO2015.0142.

Sok, J., Borges, J. R., Schmidt, P., \& Ajzen, I. (2020). Farmer behaviour as reasoned action: A critical review of research with the theory of planned behaviour. Journal of Agricultural Economics, 72(2), 388-412.Available at: https://doi.org/10.1111/1477-9552.12408.

Sorrell, S. (2015). Reducing energy demand: A review of issues, challenges and approaches. Renewable and Sustainable Energy Reviews, 47, 74-82.Available at: https://doi.org/10.1016/j.rser.2015.03.002.

Susanto, Z. A., Siswandari, W., \& Rujito, L. (2019). Cd60 (GTG > GAG)/Hb Cagliari mutation was found in scanning of $\beta$ thalassemia alleles from patients of East Kalimantan, Indonesia. Molecular Genetics and Metabolism Reports, 22, 100550.Available at: https://doi.org/10.1016/j.ymgmr.2019.100550.

Syarifudin, D., \& Ishak, R. F. (2020). The importance of rural social productive space to increase the social capital of agribusiness community in agropolitan area. Regional and Environmental Journal, 8(1), 67-83.Available at http://dx.doi.org/10.14710/jwl.8.1.67-83.

Tavakol, M., \& Dennick, R. (2011). Making sense of Cronbach's alpha. International Journal of Medical Education, 2, 53-55.Available at: https://doi.org/10.5116/ijme.4dfb.8dfd.

Udemezue, J., \& Osegbue, E. (2018). Theories and models of agricultural development. Annals of Revierws and Research, 1(5), 555574.Available at: https://doi.org/10.19080/arr.2018.01.555574.

Wang, T., Du, C., Nie, T., Sun, Z., Zhu, S., Feng, C., \& Liang, Q. (2020). Spatiotemporal analysis of maize water requirement in the Heilongjiang Province of China during 1960-2015. Water, 12(9), 2472.Available at: https://doi.org/10.3390/w12092472.

Whelan, J., \& Msefer, K. (1996). Economic supply \& demand. MIT System Dynamics in Education Project. Retrieved from https://ocw.mit.edu/courses/sloan-school-of-management/15-988-system-dynamics-self-study-fall-1998-spring1999/readings/economics.pdf.

Wijaya, A., Zainurossalamia, S., \& Darma, D. C. (2020). Life-cycle hypothesis for consumption pattern: Example from Indonesia. International Journal of Advanced Science and Technology, 29(4), 4712-4720.

Wijaya, S. (2019). Indonesian food culture mapping: A starter contribution to promote Indonesian culinary tourism. Journal of Ethnic Foods, 6(1), 9.Available at: https://doi.org/10.1186/s42779-019-0009-3.

Wijaya, A., Darma, S., \& Darma, D. C. (2020). Spatial interaction between regions: Study of the East Kalimantan Province, Indonesia. International Journal of Sustainable Development and Planning, 15(6), 937-950.Available at https://doi.org/10.18280/ijsdp.150618.

Wirtz, J., So, K. K. F., Mody, M. A., Liu, S. Q., \& Chun, H. H. (2019). Platforms in the peer-to-peer sharing economy. Journal of Service Management, 30(4), 452-483.Available at: https://doi.org/10.1108/JOSM-11-2018-0369.

Xie, F., Gao, L., \& Xie, P. (2020). Supply-side structural reforms from the perspective of global production networks - based on the theoretical logic and empirical evidence of political economy. China Political Economy, 3(1), 93-119.Available at: https://doi.org/10.1108/CPE-05-2020-0008.

Yi, F. (2017). Research on the factors affecting consumer purchase behavior of green agricultural products. Advances in Social Science, Education and Humanities Research, 156, 445-448.Available at: https://doi.org/10.2991/seiem-17.2018.111.

Yijo, S., Asnawati, A., Darma, S., Achmad, G. N., Arizandi, M. A. P., Hidayati, T., \& Darma, D. C. (2021). Social experiments on problems from tomato farmers during Covid-19-Indonesia case. SAR Journal - Science and Research, 4(1), 7-13.Available at: https://doi.org/10.18421/SAR41-02.

Zyl, J. (1989). Agricultural development principles: Economic theory and empirical evidence. Development Southern Africa, 6(1), 119-121.Available at: https://doi.org/10.1080/03768358908439452. 